\title{
Marketing Social Marketing in the Social Change Marketplace
}

\author{
Alan R. Andreasen
}

Social marketing faces significant barriers to growth because there is no clear understanding of what the field is and what its role should be in relation to other approaches to social change. However, growth is possible through increases in social marketing's share of competition at the intervention, subject matter, product, and brand levels. The author proposes a specific social marketing branding campaign to advance the field, with roles for academics and the American Marketing Association.

$\mathbf{S}$ ocial marketing is now in the growth phase of its product life cycle. However, it is at risk of not meeting its full potential because of several barriers that are in part problems of perception. The barriers are also the result of the absence of a clear understanding of what the field is and what its role should be in relation to other approaches to social change. After a brief historical introduction, this article lists major barriers to growth and then proposes a branding strategy that uses the field's own concepts and tools to promote its advancement. It is argued that growth is possible at several competitive levels. At the "intervention" level, social marketing can succeed by increasing the proportion of interventions that emphasize individual change (social marketing's niche) over approaches that emphasize community mobilization or structural change. Social marketing can also grow by increasing its brand share within the "individual change" marketplace. A final growth strategy is one that increases social marketing's use as a complement to the other two major intervention approaches.

The article proposes a specific social marketing branding campaign to advance the field-again using the field's own concepts and tools. The article concludes with suggestions for various interested parties, including academics and the American Marketing Association. It proposes building blocks that need to be put in place to achieve a future for social marketing that can positively address serious world problems while providing important personal satisfactions to the marketing practitioners and academics who become involved.

\section{Some History}

Originally stimulated by an article by a sociologist, G.D. Wiebe (1951-52), in the 1950s, social marketing's intellectual roots within the marketing field are found in Kotler and Levy's (1969) and Kotler and Zaltman's (1971) work (see also Elliott 1991). Its roots as a practice go back as least as far, beginning with family planning applications in the

Alan R. AndREAsen is Professor of Marketing, McDonough School of Business, Georgetown University. The author gratefully acknowledges the helpful comments of the three anonymous $J P P \& M$ reviewers. 1960s (Harvey 1999; Manoff 1975). Within academic marketing, its introductory period lasted perhaps 20 years, during which time social marketing struggled to establish a separate identity (Bartels 1974; Luck 1974) while broadening its scope (Andreasen 2001b).

There are now several indicia that attest to the broad acceptance of this field. Conceptual and theoretical indications include the following:

-Several general textbooks (Andreasen 1995; Kotler and Roberto 1989) have been published, along with several specialized management books.

- Chapters devoted to social marketing are now included in basic marketing textbooks (Baker 1999), nonprofit marketing books (Sargeant 1999), and health communications readers (Glanz, Lewis, and Rimer 1999).

-A journal entirely devoted to the area, the Social Marketing Quarterly, was founded in 1994.

-There are now three annual social marketing conferences, and the first Innovations in Social Marketing Conference produced a major readings book in 1997 (Goldberg, Fishbein, and Middlestadt 1997).

-Social marketing centers have been established in Scotland, Canada, and Poland, and social marketing training programs have been held in several parts of the world.

-The Social Marketing Institute was established in 1999.

On the practice side, signals of growth include the following:

-Social marketing approaches have been adopted by a wide range of U.S. federal agencies, most prominently the U.S. Department of Agriculture (5-a-Day program) and the Centers for Disease Control and Prevention, as well as state and local governments and a significant number of nonprofit organizations (see examples at www.social-marketing.org).

-UNAIDS has recently invoked social marketing as a primary tool in its fight against AIDS, and the World Bank is regularly conducting distance learning sessions using social marketing concepts.

- Requests for proposals for social change programs at federal and state levels and by nonprofit organizations now frequently require social marketing components and social marketing capabilities.

- Several major consulting organizations, most prominently Porter Novelli, Academy for Educational Development, and Prospect Center, have emerged as leading social marketing

Vol. 21 (1) 
consultants and have been joined by a growing number of smaller consultancies such as Equals3 and Sutton Social Marketing.

- Major advertising and public relations organizations such as Fleishman Hillard, Burson Marsteller, and Ogilvy Mather now claim specific social marketing capabilities.

-Senior executives with "social marketing" in their titles have begun to appear.

-Interest in social marketing has grown significantly beyond North America and the United Kingdom, and particularly innovative work has gone on in Australia and New Zealand (Donovan 1999; Donovan and Owen 1994; Stannard and Young 1998).

Probably the most significant development during this recent growth period has been the migration of social marketing from its initial close identification with the marketing of products involved in social change (condoms, pills, oral rehydration solution) to a broader conception of its potential areas of application. This pattern is consistent with a general model of intersector transfer of marketing concepts and tools from the commercial to the nonprofit sector (Andreasen 2001b). Social marketers, both scholars and practitioners, have come to accept that the fundamental objective of social marketing is not promoting ideas (as Kotler and Zaltman [1971] suggest) but influencing behavior (Andreasen 1994). It is also recognized that, though products are often involved in behavior change processes, social marketing can also apply to such purely behavioral challenges as keeping girls in school in developing countries (Schwartz, Middlestadt, and Verzosa 1994), inducing parents to stop abusing their children (Stannard and Young 1998), and helping teens resist smoking (McKenna, Gutierrez, and McCall 2000; Pechmann and Reibling 2000; Zucker et al. 2000).

Social marketers understand that their challenge of generating behavior change is no different from that of commercial sector practitioners, who are rewarded only if they "move the needle," not simply create great advertising, clever positioning, or great slogans. However, as Bloom and Novelli (1981) note, the challenges social marketers face are significantly more daunting.

\section{Barriers to Further Growth}

Although the developments mentioned previously signal robust growth and considerable promise, leaders of the field remain concerned lest the upward movement should plateau prematurely before social marketing's full potential is realized. History suggests that this is a real possibility. In earlier decades in marketing and public policy, a lack of stewardship for a research stream marked the death knell of study of the socially important problems of disadvantaged consumers (Andreasen 1978).

This concern was the focus of a "summit" of social marketing leaders convened by Porter Novelli in 1996 and a later conference at The Robert Wood Johnson Foundation in 1998 that recommended the establishment of a "center for integrated social marketing." Both events led to the founding of the Social Marketing Institute in $1999,{ }^{1}$ which began

${ }^{1}$ Further information on the institute is available at www.socialmarketing.org. its activities by systematically identifying significant potential barriers to growth for the field. A series of more than 300 personal interviews, 100 field questionnaires, and two focus groups identified four major problem areas: 2

1. There is a lack of appreciation of social marketing at top management levels. Social marketing has achieved significant acceptance among practitioners at the operations level of implementing organizations and within the consulting community to which they turn for help. However, both groups lament that leaders of too many nonprofit organizations and major government agencies are unaware either of social marketing or of its potential for organizing and implementing major social change programs. Because of this lack of appreciation, promising campaigns often are unable to use social marketing approaches or, when they do, find themselves inadequately funded or their results not thoroughly implemented.

2. The field has poor "brand positioning." Social marketing as an approach to social change lacks clarity and is perceived by key influential people as having several undesirable traits. First, the field's image is fuzzy because there are too many definitions of social marketing being used, and these definitions conflict in major and minor ways. Second, social marketing is not adequately differentiated from its competition, especially in ways that would be in its favor. Third, social marketing is perceived to have attributes that are unattractive to important target audiences-most prominently, the perception that social marketing is manipulative and not "community based." The latter is a trait that is particularly important to many agencies and foundations that are involved in international development (Gray-Felder and Deane 1999).

3. There is inadequate documentation and publicity of successes. Any social change approach gains favor to the extent that it can document its effectiveness-and, particularly, its superiority to alternatives. Furthermore, such documentation must be followed by adequate publicity that, in major part, makes clear that it is social marketing that has made the difference. Although many successes exist, these are not widely known or appreciated-and there are not enough of them. ${ }^{3}$

4. Social marketing lacks academic stature. Measures of the legitimacy of a field include the extent to which it (1) is taught on a regular basis at major universities, (2) leads to specific career options (and so merits formal learning), (3) is supported by a significant base of conceptual and theoretical material, and (4) is an accepted area of research study that increases the field's conceptual and theoretical base-and sometimes makes contributions to other fields to which it is related. Social marketing is taught only rarely as a full academic course; more often it is taught in one or two class sessions in a marketing, communications, or public health course. No institution grants a formal degree in the field or even a specialization. However, the field is slowly developing a significant foundation of conceptual and theoretical underpinnings, as is reflected by the growing number of solid studies appearing in such venues as Journal of Public Policy \& Marketing, Social Marketing Quarterly, and Journal of Marketing, among others.

2Significant roles in this research effort were played by Karen Gutierrez, Lynn Doner, Andrew Larson, Terry Baugh, and Sally Bloomberg.

${ }^{3}$ See the "Success Stories" on the Social Marketing Institute's Web site at www.social-marketing.org. See also Carroll, Craypo, and Samuels (2000) and Alcaly and Bell (2000). 


\section{Solutions: Branding Social Marketing}

Approaches to solving any problem, whether commercial or social, gain favor when they are widely perceived as superior to alternatives. This applies to innovations in software, cooking, health care, and golf. The fundamental problem for social marketing, noted previously, is that it is neither widely known nor perceived to be plainly superior to its competition in a clearly defined set of situations. I believe that the solution is found in the marketing discipline itself. I propose that social marketing should be considered a brand in the marketplace of social change approaches-and one that needs better marketing.

In my view, the challenge lies in improving the field's ability to compete at four different levels. Attention to the issues at each of these levels will force the field to address the four barriers identified previously in a more rigorous and systematic way. However, the ultimate test will be whether social marketing can be established as a superior approach in specific cases that involve specific social programs.

\section{Competition in the Field of Social Change}

Social marketing is one of many approaches to social problems and faces competition at five levels, which I have labeled generic, intervention-level, subject-market, product, and brand.

\section{Generic Competition}

At the generic level, social marketing shares the challenge faced by all systematic approaches to creating change: Namely, it competes with lethargy and habit. There are many programs, organizations, and people that do not believe in the need for an orderly, organized approach to bringing about change (like social marketing). These are the managers who disdain philosophies of management and think that good leaders need no further qualifications than to be enthusiastic, be innovative, give praise, and point optimistically toward a brighter future. Though not unknown in the private sector, such managers are more typical in the nonprofit world, where charisma and motivational talent often carry the day in the early years of an institution's life. Although social marketing would surely benefit from any increase in the number of managers adopting any kind of planned approach to social change, promoting such generic change is beyond the capacity of such a small emerging field.

\section{Intervention-Level Competition}

The relevant literature suggests that there are three societal levels at which strategists believe that interventions bring about dramatic social change. First, there are those who believe that it is individuals who ultimately must behave differently if major social problems such as drunk driving, teen smoking, or the spread of AIDS are to be reduced or eliminated. This class of interventions focuses on individual change and is practiced by many social workers, educators, and psychologists, as well as social marketers. This is social marketing's primary niche.

Second, other commentators believe that, particularly for major social changes, whole communities must be the focus of interventions (see Farquar et al. 1985). They argue that social norms, interpersonal influence, diffusion processes, and local leadership are powerful determinants of how social problems are addressed-and their impact can be for good or evil. The motivation for change must ultimately come from the community, and therefore the community must play a major role in the design, implementation, and evaluation of programs. These commentators believe that the transformation of community norms and values and the invocation of interpersonal influence will sweep individuals along and, further, that the creation of community institutions along the way will ensure the sustainability of programs-something that is often missing in individual-based initiatives. Advocates of intervention approaches at this societal level include social workers, community mobilizers, anthropologists, and sociologists (e.g., Gray-Felder and Deane 1999).

The third approach to social problem solving is offered by those who believe that social change should not be addressed at either of the first two levels, because the discretion of individuals and communities-their ability to change-is materially constrained by social structures, such as socially constructed laws, institutions, available technology, and public policies. Thus, this group argues, people die in highway crashes because speed limits are too high and not rigorously enforced, roads are poorly designed, and car manufacturers lack sufficient incentives to make their cars safer. The structuralists argue that urging people to slow down and wear seat belts will have only a small impact, whereas real change will occur if laws are changed, roads are redesigned, and automakers are given regulations or incentives to build safer vehicles. Adherents of the third approach focus on media advocacy, policy change, the use of the courts, and lawmaking to achieve social ends (Wallack 1990). To the extent that social marketing is perceived as an individual-level intervention, increased prominence of this level would benefit the field's growth.

\section{Subject-Market Competition}

Practitioners, policymakers, and foundations all make distinctions among types of social problems and issues on the basis of the broad subject matter involved. Thus, there are issues involving health care, the environment, crime, social welfare, the arts, and so on, each with its own subareas and specialties. Each subject has its own set of experts, journals, conferences, and federal and state administrators. Foundations often specialize by subject area, and practitioners choose careers within them. These practitioners and organizations compete for government budgets, talent, foundation priorities and dollars, volunteers, media attention, and, ultimately, a high place on "the public agenda." To the extent that social marketing has achieved wider acceptance and greater market share in some subject-markets (e.g., health care), the growth of these markets would significantly benefit the field.

\section{Product Competition}

Within each intervention level and subject matter area, there exist broad classes of intervention tools I label "products." Kotler and Roberto (1989, p. 20) propose five types of major change strategies (products) that include social mar- 
keting, technology, economics, politics and law, and education. Rothschild (1999) classifies the alternatives into three categories: education, marketing, and the law. Both sets of authors make clear that the role for marketers is primarily useful at the individual intervention level and involves the crafting of programs using well-tested commercial concepts and tools to induce voluntary personal change-as opposed to, say, passing laws to force people to act or merely educating people, hoping they will act. These authors would agree that, to the extent that funders and program managers believe that inducing voluntary personal social change is a superior product, social marketing as a field will dramatically grow.

\section{Brand Competition}

The final level of competition faced by social marketers is within the category of voluntary personal change programs, what I label "brand competition." Social marketing is only one of many sets of concepts and tools that organizations can use to bring about voluntary individual change. Although it is true that social marketers borrow liberally from these alternative approaches as others borrow from it (Hill 2001), it differs in the basic set of premises from which its interventions are developed. Some of the alternative approaches include

1. Stages of change approaches (Prochaska and DiClemente 1983), which emphasize tailoring interventions to the stage the target audience is in along the road to high-involvement behavior change;

2. The health belief model (Rosenstock 1990), which emphasizes communicating information about the risks and benefits of action so as to change the knowledge, attitudes, and intentions of target individuals;

3. Social learning theory (Bandura 1997), which, among other features, emphasizes building up the target audience's sense of self-efficacy: their belief that they can make the behavior happen (for applications, see Perry, Baranowski, and Parcel 1990; Perry et al. 1988);

4. Behavioral reinforcement theory (Bickel and Vuchinich 2000; Rothschild 1999), which emphasizes the manipulation of rewards and punishments in the environment surrounding desirable and undesirable behaviors;

5. Strategic communications (e.g., health communications and health promotion), which emphasizes the creation of appropriate and powerful messages to bring about change; and

6. Enter-educate programs (Piotrow and Coleman 1992), which combine educational messages with entertainment to change behaviors.

Again, social marketing will grow to the extent that it wins the "brand competition."

\section{Competition Versus Competitors}

Before considering how social marketing might compete better at these various levels, it is important to distinguish the competition among approaches from competition among enterprises. Failure to understand this distinction significantly confuses the debate and compromises social marketing's ability to distinguish itself in the social change marketplace.

There are many enterprises-commercial, governmental, and nonprofit— that design, implement, and monitor social change programs. These include international agencies such as the World Bank; federal and state agencies such as the Centers for Disease Control and Prevention; private firms such as Porter Novelli and Prospect Center; large nonprofit consultants such as the Academy for Educational Development; university centers such as Johns Hopkins' Population Information Program; smaller consultancies such as Equals3; and major foundations such as the Kellogg Foundation, The Robert Wood Johnson Foundation, and the Rockefeller Foundation.

These organizations differ from one another in the approach or approaches they bring to bear on social problems. Some, such as Johns Hopkins' Population Information Program, emphasize specific tools such as education in an entertainment context, whereas others are more eclectic. What is confusing is that many organizations claim, at least in part, to have social marketing skills or to be social marketing specialists but are guided more by approaches that are not really social marketing or that incorporate only some elements of social marketing. This muddies the competitive waters, making it difficult for outsiders-that is, potential adopters of social marketing-to understand what they might be gaining if they hire a person or organization that claims to approach a problem from a social marketing framework. How can critical gatekeepers and funderssuch as heads of federal agencies or foundation program officers-distinguish between what an enterprise does that can be properly considered social marketing from other tools and approaches that it may bring to a particular challenge but that are not social marketing?

\section{Social Marketing's Competitive Positioning}

I argue here that if it is to reach its maximum potential, social marketing must pay attention to competitive challenges at all levels except the generic level while finding ways to disentangle the confusion between the social marketing approach and the enterprises that claim they are practicing it. In my view, this is a problem in competitive positioning, and the problem will be solved when social marketing's advocates can answer the following questions:

1. What is the irreducible essence of social marketing that enables the careful observer to recognize it when he or she sees it?

2. How can it be determined whether a person claiming to be a social marketer is, in some sense, qualified to make such a claim?

3. When can social marketing be used to address some aspect of a social problem?

4. When should social marketing be used?

A critical challenge implicit in the last question is, Does it work? If advocates cannot identify when and how a social marketing approach has been especially effective, their enthusiasm is not justified.

\section{The Essence of Social Marketing}

In a recent review of the health promotion literature between 1982 and 1996, Hill (2001) finds 93 articles involving social marketing. They were of three types: case studies, tool 
applications, and conceptual debates. Conceptual debates have been particularly vigorous (Blair 1995; Bonaguro and Miaoulis 1983; Buchanan, Reddy, and Hossain 1994; Grace 1991; Hastings and Haywood 1991, 1994; Lefebvre and Flora 1988; Maben and Clark 1995; McBrien 1986; Syre and Wilson 1990; Timmereck 1987; Tones 1994; Winett 1995), and no clear consensus has emerged. In the field of marketing, authors have offered several definitions, the most frequently quoted being Kotler and Zaltman's (1971) definition, which is reinforced by Kotler and Roberto (1989, p. 24):

Since [1971], the term has come to mean a social change management technology involving the design, implementation, and control of programs aimed at increasing the acceptability of a social idea or practice in one or more groups of target adopters. It utilizes concepts of market segmentation, consumer research, product concept development and testing, directed communication, facilitation, incentives, and exchange theory to maximize the target adopter's response.

My definition is similar in that I conceive of social marketing not as a theory or a unique set of techniques but as a process for developing social change programs that is modeled on processes used in private sector marketing (Andreasen 1994). However, I have differed vigorously with Kotler and Roberto, arguing that "increasing the acceptability of a social idea" is not what social marketing is all about. As in the private sector, the ultimate objective should be behavior change-as a typical hard-charging marketer might say, "If you don't move the needle, you are not being a successful marketer." Simply gaining acceptance of an idea without inducing action is not success. Indeed, this approach is more appropriately labeled "education" or "attitude change."

As I argue, what makes social marketing potentially unique is that it (1) holds behavior change as its "bottom line," (2) therefore is fanatically customer-driven, and (3) emphasizes creating attractive exchanges that encourage behavior (the benefits are so compelling and the costs so minimal that everyone will comply). These tenets, in turn, imply central roles for consumer research, pretesting, and monitoring; for careful market segmentation; and for strategies that seek to provide beneficial, popular, and easy-toimplement exchanges to target audience members. Therefore, I propose that the benchmarks for identifying an approach that could be legitimately called social marketing are the following:

1. Behavior-change is the benchmark used to design and evaluate interventions.

2. Projects consistently use audience research to (a) understand target audiences at the outset of interventions (i.e., formative research), (b) routinely pretest intervention elements before they are implemented, and (c) monitor interventions as they are rolled out.

3. There is careful segmentation of target audiences to ensure maximum efficiency and effectiveness in the use of scarce resources.

4. The central element of any influence strategy is creating attractive and motivational exchanges with target audiences.

5. The strategy attempts to use all four Ps of the traditional marketing mix; for example, it is not just advertising or communications. That is, it creates attractive benefit packages (prod- ucts) while minimizing costs (price) wherever possible, making the exchange convenient and easy (place) and communicating powerful messages through media relevant to-and preferred by - target audiences (promotion).

6. Careful attention is paid to the competition faced by the desired behavior.

At this stage of the field's development, I do not argue that programs must have all six elements in strong measure to qualify for the label "social marketing." It is inevitable that many will have heavy doses of advertising-because this is one thing marketers do well-and more limited roles for other elements of the marketing mix. However, campaigns that are purely communications campaigns are not social marketing. Indeed, it is when campaigns move beyond mere advertising that the power of the approach is manifested.

\section{An Illustration: Census 2000}

Although the subject area in which social marketing has its deepest market penetration is health care, a dramatic example of the approach is illustrated in the successful marketing of Census 2000. This campaign got off on the right foot by being clear about the specific behavior it wanted to achieve: high rates of response to the Census questionnaire. Voluntary participation had been declining steadily from $78 \%$ in 1970 to $65 \%$ in 1990 . It was predicted to fall farther to $61 \%$ in 2000 .

Census Bureau customer research identified ethnic and racial minorities as target groups that had especially low response rates in the last Census-a problem that, especially for immigrants, was expected to worsen significantly in 2000. Furthermore, the bureau noted that children represented more than $50 \%$ of the undercount. These two populations became the focus of special efforts. With respect to the former, the bureau hired five advertising agencies-a lead agency (Young \& Rubicam) and four other groups that specialized in such diverse populations as audiences from Poland and Arab-speaking countries, Native Americans, and Alaskan natives (James 2000). A significant "Census in Schools" program was also developed for children in cooperation with Scholastic Inc.'s Social Marketing Solutions group. This program provided teaching materials and takehome brochures to every school in the United States to ensure that children learned about and supported the Census and brought home information-and perhaps subtle influence- to their parents.

The overall strategy focused intensively on the exchange asked of citizens - telling them that the Census will provide vital information that will mean more and better resources for them and their community. More than 250 advertisements for television, radio, print, outdoors, and the Internet were developed in 17 languages and placed in donated and paid media with a budget of more than $\$ 167$ million. To ensure that target audiences had a sense of self-efficacy, more than 140,000 partner organizations were recruited to promote cooperation and provide instruction. Census kits were sent to teachers of new immigrants, and 12 road tour vehicles traveled the country, teaching 2 million visitors how to fill out forms.

As good social marketers, campaign leaders carefully pretested the entire strategy in two cities in April 1998 with 
significantly positive results. The planning and testing paid off dramatically, achieving a cooperation rate of $67 \%$ in 2000. This performance saved the Federal treasury in enumeration costs many times the dollars spent on the social marketing effort. 4

\section{Who Is a Social Marketer?}

Any practitioner who systematically attempts to employ the previous six characteristics can legitimately claim to be following a social marketing approach. Therefore, until such time as the field adopts a certification program such as the one recently initiated by the American Marketing Association for private-sector marketers, this template might be used to judge the extent to which a given person or firm is truly a social marketer.

For academics, the criteria need to be somewhat different. Academics contribute both conceptual frameworks and insights (e.g., Goldberg 1997; Rothschild 1999) and careful research studies on all facets of the basic practitioner approach. Thus, researchers exploring the effectiveness of alternative messages for social marketing campaigns (Maibach and Cotton 1995; Pechmann and Reibling 2000), possible social marketing segmentation strategies (Donovan 1999), alternative consumer behavior models (Hornik 2001b), or the outcomes of specific campaigns (Lefebvre and Flora 1988) can all be said to be contributing to the field of social marketing and, in that sense, to be social marketers.

\section{When Can Social Marketing Be Used?}

Social marketing can be applied in any situation in which a socially critical individual behavior needs to be addressed for a target audience. This gives social marketing a wide domain. It is most typically thought of as applying to "final customers"- -such as teens who smoke or mothers who need to have their children immunized. However, as noted subsequently, it is important to realize that a social marketing approach can also apply to bringing about behavior changes in other key players whose cooperative actions are needed to make programs successful. These can include members of the media, potential partners, funders, policymakers, legislators, and an organization's own staff. The principles and themes of a good social marketing campaign can be used to influence all these target audiences.

\section{When Should Social Marketing Be Used?}

Although social marketing can be used in many kinds of interventions, it may not always be the best approach. There are two criteria by which such decisions can be made, effectiveness and appropriateness. Social marketing should be adopted only in specific situations in which it is likely to be effective. Effectiveness, however, only sets the outer boundaries for potential application. There is still the question of when it is appropriate to use social marketing. The first question involves the marshalling of evidence. The second involves matters of informed judgment and ethics.

\section{Effectiveness}

Social marketers are beginning to accumulate data on a wide range of campaigns that can be cited as examples of social

\footnotetext{
${ }^{4}$ For further information, see the Census Web site at www.census 2000.
} gov. marketing and are reporting positive results. For example, both The Futures Group and Population Services International have developed an extensive series of reports on their work. Scholars at the Center for Advanced Studies in Nutrition and Social Marketing have documented effectiveness in the area of nutrition (Alcaly and Bell 2000; Carroll, Craypo, and Samuels 2000). Robert Hornik (2002) of the Annenberg School of Communications at the University of Pennsylvania has recently edited a series of articles assessing behavioral impacts of health promotion campaigns.

However, as Hornik and others have noted, evaluation of the effectiveness of social marketing interventions is difficult. In each case, three questions must be asked: (1) Was the campaign truly an example of social marketing or, for example, was it merely a communications campaign? (2) Was it truly effective in that it reported actual behavioral outcomes (not just increases in awareness or attitude change)? and (3) Did it demonstrate that social marketing itself played a significant role (i.e., caused) the positive result? As Hornik (2001) points out, most important social campaigns involve a wide range of potentially influential interventions plus secular change that collectively make it difficult to identify specific effects. For example, it is widely believed that social marketing has played an important role in reducing national smoking rates, which have shown a long-term downward trend. However, it is difficult to assess the relative contributions of promotional messages, media coverage, price increases, smoking restrictions, changes in point-of-sale regulations, reduction in the depiction of smoking in movies and on television, the Surgeon General's Reports and speeches, and so forth (Calfee 1997).

\section{Appropriateness}

Even if social marketing is likely to be successful in a specific context, there are still two issues: (1) Is it the best approach in the context? and (2) Is it ethical to use social marketing rather than some other approach (Andreasen 2001a)? These questions go back to a consideration of social marketing and its competition. Social marketing is, at base, a brand of individual behavior change. Thus, starting at the intervention level, the first question is whether a program should emphasize structural change, individual change, or community mobilization. When that is decided, the next question is whether inducing voluntary individual behavior is the right product for the situation being faced or whether the law, education, or technology should be emphasized. Then, finally, is social marketing the best brand of voluntary individual change?

These are difficult decisions that program managers must make all the time. The answers are not easy. Take the case of AIDS prevention programs. One U.K. health specialist grappled with the question whether to adopt structural- or individual-change approaches as follows:

Whilst I firmly believe in prioritising social and structural change over individual behaviour change, there is room for both, though the balance seems to depend on the context you're working in. If you take HIV for example, yes, there is a strong relationship with risky behaviour, but there is an equally strong, if not stronger, relationship with "risky conditions." Take Africa, for example: What use is it to promote condom use to a population where condoms - when they are available-represent such a significant part of the budget, [when other national] 
needs must be sacrificed in order to make them available, where women's ability [to] "ask" men to use condoms is undermined by their lower social status, where rape is seen as a legitimate weapon of war...? In this context, surely it is neither ethical nor an efficient use of one's time to try and change individual sexual behaviour. Now if you took an "ideal" society (my values here ...) where Black/White, gay/straight, men/women (no rich/ poor here!) all have equal status and access to the society's resources, now I think it would be acceptable to look at individual behaviour change strategies. However, two questions remain; would a behaviour change strategy give rise to future inequalities? Would an HIV epidemic have occurred in an "ideal" society in the first place? The general principle appears to be where all things are equal in society, look at the individual; where inequalities in society exist, "change" these first. (King 2001)

\section{Reframing Intervention-Level Competition: A Complementary Solution}

Part of the preceding argument suggests that social marketing can grow in its impact to the extent that more social issues are defined as more amenable to individual change approaches than to community mobilization or structural change. Then, social marketing's only challenge is to make a powerful case that it is superior to technology or education products or to health promotion or social learning brands. I argue that social marketing can also grow to the extent that it can be perceived as complementary to rather than competitive with community and structural approaches. To the extent that the last two approaches require the actions of individual people (e.g., community activists, politicians), social marketing can help.

A useful framework for considering these possibilities is one adapted by Rothschild (1999) from Petty and Cacioppo (1986) and MacInnis, Moorman, and Jaworski (1991). Rothschild argues that the appropriateness of a particular type of intervention depends on the motivation, opportunity, and ability to act of the target audience. Motivation, opportunity, and ability determine whether a person is likely to be prone, resistant, or unable to behave. In my view, this can be the starting point for an analysis of which approach-structural, community, or individual-is best or, more likely, how the three approaches might work together.

Some possibilities are presented in Figure 1, which suggests how approaches from each intervention framework

Figure 1. Possible Collaboration of Approaches Given the Source of Barriers to Action

\begin{tabular}{|c|c|c|c|c|}
\hline Problem & Barrier & Role for Social Marketing & $\begin{array}{l}\text { Role for Community } \\
\text { Mobilization }\end{array}$ & $\begin{array}{l}\text { Role for Structural } \\
\text { Change Approaches }\end{array}$ \\
\hline \multirow[t]{3}{*}{ Motivation } & Individual & $\begin{array}{l}\text { Creating awareness; } \\
\text { promoting high benefits, } \\
\text { low costs }\end{array}$ & Urging media cooperation & $\begin{array}{l}\text { Building Web links to } \\
\text { hard-to-reach } \\
\text { people }\end{array}$ \\
\hline & Community & $\begin{array}{l}\text { Urging opinion leaders to } \\
\text { motivate others }\end{array}$ & $\begin{array}{l}\text { Creating awareness; raising } \\
\text { public concern }\end{array}$ & $\begin{array}{l}\text { Creating incentives for } \\
\text { group organization }\end{array}$ \\
\hline & Structural & $\begin{array}{l}\text { Urging change in structural } \\
\text { rewards/penalties } \\
\text { (e.g., taxes) }\end{array}$ & Holding briefings & $\begin{array}{l}\text { Changing structural } \\
\text { rewards/penalties } \\
\text { (e.g., taxes) }\end{array}$ \\
\hline \multirow[t]{3}{*}{ Opportunity } & Individual & $\begin{array}{c}\text { Creating awareness of } \\
\text { behavioral opportunities }\end{array}$ & $\begin{array}{l}\text { Urging business, political } \\
\text { cooperation }\end{array}$ & $\begin{array}{l}\text { Changing economic } \\
\text { barriers to } \\
\text { individual action }\end{array}$ \\
\hline & Community & $\begin{array}{l}\text { Urging businesses to } \\
\text { provide access to change } \\
\text { agents }\end{array}$ & $\begin{array}{l}\text { Changing repressive } \\
\text { social norms }\end{array}$ & $\begin{array}{l}\text { Eliminating antitrust } \\
\text { restriction on } \\
\text { business cooperation }\end{array}$ \\
\hline & Structural & $\begin{array}{l}\text { Urging use of government } \\
\text { facilities for programs }\end{array}$ & $\begin{array}{l}\text { Bringing pressure to } \\
\text { bear on legislators }\end{array}$ & $\begin{array}{l}\text { Providing government } \\
\text { subsidies; changing } \\
\text { physical environments }\end{array}$ \\
\hline \multirow[t]{3}{*}{ Ability } & Individual & $\begin{array}{l}\text { Providing modeling of ideal } \\
\text { behavior }\end{array}$ & $\begin{array}{l}\text { Pointing group members } \\
\text { to individualized } \\
\text { change tools }\end{array}$ & $\begin{array}{l}\text { Allowing government } \\
\text { agencies to } \\
\text { provide training }\end{array}$ \\
\hline & Community & $\begin{array}{l}\text { Providing communications } \\
\text { tools for outreach }\end{array}$ & Conducting group training & $\begin{array}{l}\text { Allowing government } \\
\text { premises (e.g., schools) } \\
\text { for group training }\end{array}$ \\
\hline & Structural & $\begin{array}{l}\text { Urging removal of public } \\
\text { disincentives }\end{array}$ & $\begin{array}{l}\text { Changing community } \\
\text { structures voluntarily }\end{array}$ & $\begin{array}{l}\text { Removing public } \\
\text { disincentives }\end{array}$ \\
\hline
\end{tabular}


(the columns) can be applied in a coordinated fashion depending on whether the root source of each potential motivation, opportunity, and ability barrier is primarily individual, community, or structural (the rows). Figure 1 makes clear the significant potential for cooperation among the three approaches.

Thus, for example, if the problem is lack of motivation, various players could play the following roles:

1. If the barriers are at the individual level, the social marketing approach would play a key role, focusing on creating awareness and promoting the significant benefits and low costs of the behavior (i.e., that there is a desirable exchange). Community mobilizers might help secure media cooperation, and structuralists might help fund Web links for reaching target audiences (e.g., in rural areas).

2. If the barrier is the community, social marketing can be used in a supplemental role by practitioners who adopt a community mobilization approach in helping influence key opinion leaders to support changes in norms.

3. If the key barrier is structural, social marketing can be used to influence legislators to change rewards and penalties for the desired action.

To date, consideration of potential complementary relationships among the three approaches has rarely been observed but merits greater attention in the future. In my view, this holds as much potential for increasing the use of social marketing, as does increasing social marketing's ability to compete at the product and brand levels.

\section{Marketing Social Marketing}

The ability of social marketing to become the preferred approach to individual change is by no means certain given the barriers enumerated in the beginning paragraphs of this article. Here, I suggest, is a chance for social marketers to apply their own technology to their own problem. That is, if social marketing is to gain significant market share among individual change approaches and to be used in a complementary fashion with community and structural approaches, then its proponents must effectively market social marketing, in the process demonstrating through their own actions the power of the approach. Winning this competition is a matter of individual behavior change, in which the target audience comprises decision makers at agencies, programs, and foundations who might adopt a social marketing approach.

How might they be convinced? In my approach to social marketing (Andreasen 1995), I argue that high-involvement behaviors such as those discussed here (1) come about in stages (as Prochaska and DiClemente [1983] also propose) and (2) are ultimately driven by four factors that I have since called the "BCOS factors"- - benefits, costs, others, and selfefficacy. The four factors are another way of employing the exchange framework (benefits versus costs) that are unique to marketing but modifying it to explicitly consider other elements that make the behavior not only desirable but also-following William Smith's mantra-easy and popular.

Therefore, a first step in developing a campaign to market social marketing is to consider how decision makers should be approached at each stage of the behavior change process (see Maibach and Cotton 1995):
1. Precontemplation: Decision makers do not consider social marketing because they have never heard of it or because they have rejected it for some reason.

2. Contemplation: Decision makers are considering social marketing.

3. Preparation/action: Decision makers are convinced that social marketing is a good thing but have not yet begun a social marketing campaign.

4. Maintenance: Decision makers have tried social marketing but are not yet regular users of the approach.

\section{Influencing Precontemplators}

In my experience, the challenge with precontemplators is to dispel some of the myths or preconceptions that stand in the way of social marketing. Among these are the following:

1. Marketing is manipulative. For many broadly based campaigns, funders and program directors are strongly committed to community participation in setting program goals and designing program elements. Many in this group believe that social marketing is driven by community "outsiders" who use powerful advertising and related approaches to impose the marketer's preferences (e.g., Western ideas) on the target population. Yet one of the central tenets of social marketing is to be fanatically customer driven. Social marketers must convince skeptical funders and program managers that, in contrast to what they might think, social marketing is specifically constrained by its underlying philosophy to incorporate community views at all steps of its approach.

2. Marketers are shallow and unethical, and associating with them will diminish the stature of programs. Unfortunately, this is a perception that taints the entire marketing profession, not just social marketing. It stems from observations of bad marketing and the practices of incompetent marketers (e.g., intrusive and unprofessional telemarketing). Bad marketers usually view the task as selling - convincing customers to do what the marketer wants them to do and not constructing marketing offers to meet customer needs (Andreasen 1982). Bad marketers perceive the customer as an enemy to be coerced into doing the right thing - that is, buying the marketer's offering. But good (social) marketing is committed to following the dictates of its target audience's needs, wants, and perceptions. Good marketing attributes lack of success not to audience ignorance or pigheadedness but to the marketer's lack of full understanding and response to "where the customer is coming from."

3. Marketing is too expensive. Marketing in both the private and social sectors is perceived by many people as expensive, because it involves extensive advertising campaigns. To some extent, this myth is perpetuated when marketers demonstrate social marketing by showing off their best media efforts. However, as mentioned previously, social marketing is not any one of the four Ps; it is a process, a way of thinking about and implementing behavior change that involves many elements. In many cases, it need not involve advertising at all. Better strategies might involve face-to-face interventions, the use of the Internet, increases in behavioral opportunities, and so on-and no media advertising.

4. Marketing is just putting different labels on what other brands have always done. As noted previously, it is true that many of the elements of social marketing are found in other approaches. A great many health communicators use formative customer research to guide strategy development. However, these other approaches lack elements that social marketers believe are critical to success and do not always focus on the behavioral bottom line. Some approaches settle for 
communications objectives (e.g., increasing knowledge, awareness, and/or attitude change) that marketers would consider only stepping stones to ultimate behavior change. However, that there is confusion about just what social marketers do beyond what others do leaves significant room for marketing social marketing itself, as is suggested in the next section.

\section{Influencing Contemplators}

For this group, it is important to focus on the BCOS factors, differentiating social marketing as clearly and dramatically as possible. This means pointing out how the benefits of adopting social marketing are significant, the costs are lower than the competition's, important others support its adoption, and it does not require significant new skills on the part of the adopter or easy acquisition of skills.

\section{Benefits}

The benefits of social marketing to be promoted include the following:

-The target audience is guaranteed to play a major role in developing and implementing the planned program.

-All program elements will be focused on behavior change instead of settling for changes short of that goal (such as changes in awareness, liking, and so forth).

-Influence attempts will be tailored to specific segments of the target audience, thus ensuring efficient use of limited resources and tactics that are more effective because they speak to the specific interests, needs, and wants of distinct groups or individuals in the target audience.

-Through the application of the four Ps, influence attempts will always move beyond the promotion of the benefits of the desired behavior by paying attention to reducing the costs of the behavior and making it popular and easy.

\section{Costs}

The costs of social marketing are primarily finding talented help. However, these costs are being reduced as follows:

-Finding competent and experienced social marketers is becoming easier, as is evidenced by the membership in the social marketing listserver (listproc@ listproc.georgetown.edu).

-Additional resources are coming online as more and more private sector marketers want to apply their professional skills to social problems (i.e., doing volunteer work that uses their specific skills more than painting a club room or ladling soup in a soup kitchen would).

\section{Others}

That others will help support the use of social marketing is evidenced in various ways:

-Social marketing is increasingly widely adopted. It has moved beyond initial applications in family planning and public health to areas such as the environment, educational opportunity, violence prevention, and even animal protection.

-There are growing venues for people who use social marketing to meet with others to share experiences, best practices, and support. This includes the listserver mentioned previously, the annual Innovations in Social Marketing Conference, and annual social marketing conferences in Clearwater, Fla., and Sacramento, Calif.

\section{Self-Efficacy}

Marketers can easily gain the skills needed for social marketing:

-As noted at the outset of this article and evidenced by the long reference list, there is a dramatically growing arsenal of written and electronic material available to marketers so they can develop familiarity and skills in using the approach. These materials can be mined for help in all stages of the design and implementation of social marketing strategies, and there are always "friends" on the listserver who can offer advice.

\section{Influencing Preparers/Actors}

This is the point at which the network of established social marketers can bring influence and the help of others can be important. The increasing accessibility of off-the-shelf tools and experienced consultants can reassure hesitant implementers that it is easy to make social marketing work.

\section{Influencing Maintainers}

Members of this group need reinforcement about the wisdom of their actions. Forums for publicizing results can be important and rewarding at this stage.

\section{What's Missing?}

The challenge is to grow the field of social marketing by (1) exploring the ways it can complement rather than compete with community mobilization and structural change at the intervention level, (2) increasing the occasions in which it is in the consideration set whenever individual behavior change is the appropriate focus of a social change program, and (3) increasing the number of times it is chosen as the preferred "brand" for individual change.

How will this happen? Several building blocks must be put in place-or expanded-for the field to reach its maximum potential. The following are critical:

1. Committed and extensive private sector involvement: Social marketing represents a unique, time-sensitive opportunity for the broader field of marketing to demonstrate that marketing is not an evil menace but a potentially powerful tool for social good. Extensive conversations with a wide range of commercial marketing professionals and with the leadership of the American Marketing Association make clear that there exists a significant untapped reservoir of potential support for social marketing in the commercial sector.

2. Creation of academic programs: Academic programs must be created at undergraduate and graduate levels to train future social marketers. This could take place in schools of business or programs in public health, pubic policy, or communications. However, because such programs do not now exist, this would require (a) creation and dissemination of course materials and cases on social marketing to academics who wish to teach social marketing, (b) creation of a curriculum that could lead to a master's degree or specialization in social marketing, and (c) creation of scholarships for students who specialize in social marketing.

3. Further legitimization of social marketing as a scholarly field of study: This is a challenge I set for consumer behavior researchers in the early 1990s (Andreasen 1993), but much remains to be done. Steps now might include (a) providing scholarships for doctoral candidates or subsidies for faculty research (e.g., leaves of absence, support for field research) that permit focus on social marketing topics, (b) creation of chairs in social marketing (another way for the private sector 
to help), (c) funding of awards for scholarly accomplishments in social marketing, (d) cooperation of practicing social marketers in academic research projects, and (e) further identification of important research topics that could be carried out in social marketing domains that will contribute to mainstream marketing scholarship and practice.

\section{Conclusion}

This is a critical juncture in the history of a new discipline. There is a chance to help it grow and to position marketing as a benevolent force in society, doing good in ways that are beyond filling people's homes and lives with new products and services. Commercial marketing and its academic allies should not pass up what can be an important opportunity to reposition the entire field of marketing. Existing "old-line" marketing institutions must step up to the plate to nurture social marketing's growth and increase its market penetration at the four levels described here. It would be sad and wasteful if much that has already been accomplished is lost and social marketing suffers the fate of previous public policy fads.

\section{References}

Alcaly, Rina and Robert Bell (2000), Promoting Nutrition and Physical Activity Through Social Marketing: Current Practices and Recommendations. Sacramento, CA: University of California Davis Center for Advanced Studies in Nutrition and Social Marketing.

Andreasen, Alan R. (1978), "The Ghetto Marketing Life Cycle: A Case of Underachievement," Journal of Marketing Research, 15 (February), 20-28.

- (1982), "Nonprofits: Check Your Attention to Customers," Harvard Business Review, 60 (3), 105-10.

(1993), "Presidential Address: A Social Marketing Research Agenda for Consumer Behavior Researchers," in Advances in Consumer Research, Vol. 20, Michael Rothschild and Leigh McAlister, eds. Provo, UT: Association for Consumer Research, 1-5.

(1994), "Social Marketing: Definition and Domain," Journal of Public Policy \& Marketing, 13 (1), 108-14. Bass.

(1995), Marketing Social Change. San Francisco: Jossey-

- ed. (2001a), Ethics in Social Marketing. Washington, DC: Georgetown University Press.

- (2001b), "Intersector Transfer of Marketing Knowledge," in Handbook of Marketing and Society, Paul N. Boom and Gregory T. Gundlach, eds. Thousand Oaks, CA: Sage Publications, 80-104.

Baker, Michael J., ed. (1999), IEBM Encyclopedia of Marketing. London: International Thompson Business Press.

Bandura, Albert (1997), Self-Efficacy: The Exercise of Control. New York: Freeman.

Bartels, Robert (1974), “The Identity Crisis in Marketing," Journal of Marketing, 38 (October), 73-76.

Bickel, Warren K. and Rudy E. Vuchinich, eds. (2000), Reframing Health Behavior Change with Behavioral Economics. Mahwah, $\mathrm{NJ}$ : Lawrence Erlbaum Associates.
Blair, J.E. (1995), “Social Marketing: Consumer-Focused Health Promotion," AAOHN Journal, 43 (10), 527-31.

Bloom, Paul N. and William D. Novelli (1981), "Problems and Challenges in Social Marketing," Journal of Marketing , 45 (2), 79-88.

Bonaguro, J.A. and George Miaoulis (1983), "Marketing: A Tool for Health Education," Health Education, 14 (1), 6-11.

Buchanan, D.R., S. Reddy, and Z. Hossain (1994), "Social Marketing: A Critical Appraisal," Health Promotion International, 9 (1), 49-57.

Calfee, John E. (1997), Fear of Persuasion: A New Perspective on Advertising and Regulation. Monnaz, Switzerland: Agora Association.

Carroll, Amy, Lisa Craypo, and Sarah Samuels (2000), Evaluating Nutrition and Physical Activity Social Marketing Campaigns: A Review of the Literature for Use in Community Campaigns. Sacramento, CA: University of California Davis Center for Advanced Studies in Nutrition and Social Marketing.

Donovan, Robert J. (1999), "Targeting Male Perpetrators of Intimate Partner Violence: Western Australia's Freedom from Fear Campaign," in Fifth Innovations in Social Marketing Conference, Charles B. Weinberg and Robin J.B. Ritchie, eds. (CDRom). Vancouver, BC: University of British Columbia.

and N. Owen (1994), "Social Marketing and Mass Interventions," in Advances in Exercise Adherence, 2d ed., R.K. Dishman, ed. Champaign, IL: Human Kinetic Books, 249-90.

Elliott, Barrie J. (1991), A Re-examination of the Social Marketing Concept. Sydney, Australia: Elliott \& Shanahan Research.

Farquar, J.W. et al. (1985), "The Stanford Five-City Project: Design and Methods," American Journal of Epidemiology, 122 (August), 323-34.

Glanz, Karen, Frances Marcus Lewis, and Barbara K. Rimer, eds. (1999), Health Behavior and Health Education, 2d ed. San Francisco: Jossey-Bass Publishers.

Goldberg, Marvin (1997), "Social Marketing: Are We Fiddling While Rome Burns?" Journal of Consumer Psychology, 4 (4), 347-70.

— Martin Fishbein, and Susan Middlestadt, eds. (1997), Social Marketing: Theoretical and Practical Perspectives. Mahwah, NJ: Lawrence Erlbaum Associates.

Grace, V.M. (1991), "The Marketing of Empowerment and the Construction of the Health Consumer: A Critique of Health Promotion," International Journal of Health Services, 21 (2), 329-43.

Gray-Felder, Denise and James Deane (1999), Communication for Social Change: A Position Paper and Conference Report. New York: The Rockefeller Foundation.

Harvey, Philip D. (1999), Let Every Child Be Wanted: How Social Marketing Is Revolutionizing Contraceptive Use Around the World. Westport, CT: Auburn House.

Hastings, Gerard and A. Haywood (1991), "Social Marketing and Communication Health Promotion," Health Promotion International, 6 (2), 135-45.

__ and __ (1994), "Social Marketing: A Critical Response," Health Promotion International, 9 (1), 59-63.

Hill, Railton (2001), "The Marketing Concept and Health Promotion: A Survey and Analysis of Recent 'Health Promotion' Literature," Social Marketing Quarterly, 7 (1), 29-53. 
Hornik, Robert (2001), "Remarks on the Occasion of the Andreasen Fellowship Lecture," paper presented at the Social Marketing and Health Conference, Clearwater, FL (June 22).

- ed. (2002), Public Health Communication: Evidence for Behavior Change. Mahwah, NJ: Lawrence Erlbaum Associates.

James, Dana (2001), "Census Says: Multiculti Works,” Marketing News, (July 30), 1, 9-10.

King, David (2001), HIV \& Sexual Health Team Co-ordinator, Barnet Health, UK, posting on the SOC-MKTG listserver.

Kotler, Philip and Sidney J. Levy (1969), "Broadening the Concept of Marketing," Journal of Marketing, 33 (January), 10-15.

and Eduardo Roberto (1989), Social Marketing. New York: The Free Press.

- and Gerald Zaltman (1971), "Social Marketing: An Approach to Planned Social Change," Journal of Marketing, 35 (July), 3-12.

Lefebvre, R. Craig and June A. Flora (1988), "Social Marketing and Public Health Intervention," Health Education Quarterly, 15 (3), 299-315.

Luck, David J. (1974), "Social Marketing: Confusion Compounded," Journal of Marketing, 38 (October), 70-72.

Maben, J. and J.M. Clark (1995), "Health Promotion: A Concept Analysis," Journal of Advanced Nursing, 22 (6), 1158-65.

MacInnis, Deborah J., Christine Moorman, and Bernard Jaworski (1991), "Enhancing and Measuring Consumers' Motivation, Opportunity, and Ability to Process Brand Information from Ads," Journal of Marketing, 55 (October), 32-53.

Maibach, Edward and D. Cotton (1995), "Moving People to Behavior Change: A Staged Social Cognitive Approach to Message Design," in Designing Health Messages, Edward Maibach and Roxanne Louiselle Parrott, eds. Newbury Park, CA: Sage Publications, 41-64.

Manoff, Richard K. (1985), Social Marketing. New York: Praeger Publishers.

McBrien, M. (1986), "Health Promotion: Education or Marketing Strategy?" Nursing Success Today, 3 (5), 16-17.

McKenna J., Karen Gutierrez, and K. McCall (2000), "Strategies for an Effective Youth Countermarketing Program: Recommendations from Commercial Marketing Experts," Journal of Public Health Management Practice, 6 (May), 7-13.

Pechmann, C. and E.T. Reibling (2000), "Planning an Effective Anti-smoking Mass Media Campaign Targeting Adolescents," JournalofPublicHealthManagementPractice, 6 (May),80-94.

Perry, C.L., T. Baranowski, and G.S. Parcel (1990), "How Individuals, Environments, and Health Behavior Interact: Social Learning Theory," in Health Behavior and Health Education, Karen Glanz, Francis Marcus Lewis, and Barbara K. Rimer, eds. San Francisco: Jossey-Bass, 161-86.

- R.V. Luepker, D.M. Murray, C. Kurth, R. Mullis, S. Crockett, and D.R. Jacobs Jr. (1988), "Parent Involvement with
Children's Health Promotion: The Minnesota Home Team," American Journal of Public Health, 78 (September), 1156-60.

Petty, Richard E. and John T. Cacioppo (1986), Communication and Persuasion: Central and Peripheral Routes to Attitude Change. New York: Springer-Verlag.

Piotrow, Phyllis T. and P.L. Coleman (1992), "The Enter-Educate Approach," Integration, 31 (March), 4-6.

Prochaska, James O. and C.C. DiClemente (1983), "Stages and Processes of Self-Change of Smoking: Toward an Integrative Model of Change," Journal of Consulting and Clinical Psychology, 51 (3), 390-95.

Rosenstock, Irwin M. (1990), "The Health Belief Model: Explaining Health Behavior Through Expectancies," in Health Behavior and Health Education, Karen Glanz, Francis Marcus Lewis, and Barbara K. Rimer, eds. San Francisco: Jossey-Bass Publishers, 39-62.

Rothschild,Michael(1999), "Carrots,Sticks, andPromises: A Conceptual Framework for the Management of Public Health and Social Issue Behaviors," Journal of Marketing, 63 (4), 24-37.

Sargeant, Adrian (1999), Marketing Management for Nonprofit Organizations. Oxford, UK: Oxford University Press.

Schwartz, Beverly, Susan Middlestadt, and Cecelia Verzosa (1994), "Social Marketing Research on Educating Girls in Bangladesh," The Forum for Advanced Basic Education and Literacy, 3 (February), 8-9.

Stannard, Sue and Joan Young (1998), "Social Marketing as a Tool to Stop Child Abuse," Social Marketing Quarterly, 4 (4), 64-68.

Syre, T.R. and R.W. Wilson (1990), "Health Care Marketing: Role Evolution of the Community Health Educator," Health Education, 21 (1), 6-8.

Timmereck, T.C. (1987), "Health Education and Health Promotion: A Look at the Jungle of Supportive Fields, Philosophies, Philosophies, and Theoretical Foundations," Health Education, 18 (6), 23-28.

Tones, K. (1994), "Marketing and the Mass Media: Theory and Myth," Health Education Research, 9 (2), 165-69.

Wallack, Lawrence (1990), "Media Advocacy: Promoting Health Through Mass Communication," in Health Behavior and Health Education, Karen Glanz, Francis Marcus Lewis, and Barbara K. Rimer, eds. San Francisco: Jossey-Bass Publishers, 370-86.

Wiebe, G.D. (1951-52), "Merchandising Commodities and Citizenship on Television," Public Opinion Quarterly, 15 (Winter), 679-91.

Winett, R.A. (1995), "A Framework for Health Promotion and Disease Prevention Programs," American Psychologist, 50 (5), 341-50.

Zucker, David, R.S. Hopkins, D.F. Sly, J. Urich, J.M. Kershaw, and S. Solari (2000), "Florida's 'Truth' Campaign: A Countermarketing Anti-tobacco Media Campaign," Journal of Public Health Management Practice, 6 (3), 1-6. 
Copyright $\odot 2003$ EBSCO Publishing 